\title{
Motivational Strategies to Improve Artisan's Productivity in the Construction Industry in Ghana
}

\author{
Timothy Adu Gyamfi ${ }^{1}$, Edward Nana-Addy ${ }^{2}$, Wiliam Gyadu-Asiedu1 \\ ${ }^{1}$ Faculty of Built and Natural Environment, Koforidua Technical University, Koforidua, Ghana \\ ${ }^{2}$ Faculty of Built Environment \& Applied Science, Sunyani Technical University, Sunyani, Ghana \\ Email: agttimo78@gmail.com, renaddy@yahoo.com
}

How to cite this paper: Gyamfi, T.A., Nana-Addy, E. and Gyadu-Asiedu, W. (2020) Motivational Strategies to Improve Artisan's Productivity in the Construction Industry in Ghana. Journal of Building Construction and Planning Research, 8, 285-301. https://doi.org/10.4236/jbcpr.2020.84019

Received: November 19, 2020

Accepted: December 27, 2020

Published: December 30, 2020

Copyright $\odot 2020$ by author(s) and Scientific Research Publishing Inc. This work is licensed under the Creative Commons Attribution International License (CC BY 4.0).

http://creativecommons.org/licenses/by/4.0/

(c) (i) Open Access

\begin{abstract}
Motivation is a strategy adopted by organisational managers to improve organisational performance. Most researchers have found different factors that affect the motivation on a different level. The aim of the survey was to examine the motivational strategies for improving productivity among artisans in the construction companies in the Eastern Region and the Greater Accra Region of Ghana. The study adopted a descriptive cross-sectional research design utilising the quantitative approach. A purposive random sampling technique was employed to choose 90 workers to participate in the study. A structured questionnaire was utilised to gather information from respondents. Statistical Package for Social Sciences (SPSS) and Partial Least Squares-Structural Equation Modeling (PLS-SEM) were used to analyse the data collected. Results from the survey showed that artisans see motivation as very significant in their workplace. The study found that empowerment, quality of life, and monetary incentive have significant relation with motivation and effective use of such strategies could assist construction industry practitioners to enhance craftsmen performance. The study contributes to a few pieces of literature existing in construction motivational strategies. The findings point to the fact that industrial players should pay more attention to the motivational strategies to assist artisans' function effectively in their work environment.
\end{abstract}

\section{Keywords}

Strategies, Empowerment, Quality of Life, Financial Incentive, Motivation, Artisan, Ghana

\section{Introduction}

The building industry is regularly labelled as an industry with numerous chal- 
lenges and a deficiency of effectiveness [1]. Many scholars have spoken about the continuous decline in the performance of the construction industry and developing challenges facing the sector [2]. The obligation of management comprises the organising human resources to accomplish organisational goals [3]. When theoreticians define motivation, three words are commonly repeated: Direction (what people choose to do); Effort; and Persistence [4] [5] [6]. When financial difficulties arise is characterised with many cut-downs as regards with, uncertain in employment and problems in salary increase, at this instance many employees who want to move towards high-self-esteem, due to employment uncertainties turned to the basic needs for food, cloth and shelter and abandoning the needs for self-esteem and self-actualisation [7]. Motivation in the organisational setting has usually been associated to matters such as job security, enthusing job, capacity to accomplish task, people acknowledgement, sufficient salary and response on performance [8]. In people's perspective, they are motivated when recognised in their institutions, as declared by the Project Management Institute (PMI) [9]. In the opinion of Currie [10] production is the quantitative association amid output and, the usage of input. However as argued by [11], a sign of efficiency is organistional usage of resources to derive product. Amadi [12] pictured the productivity ratio as amount of fuel consumed when travelled some distance, here the fuel is the input and distance covered is the output. As posited by Emery, [13] motivated sales personnel can achieve their target in a short possible time and this turns to enhance organisational sales and profit. Again, when employees are motivated, they are potential to give out their best for their organisational benefit [14].

A few numbers of literature involving construction motivation were reviewed by the study. The research by Cox et al. [15] examined construction employees and low-level supervisory staff in large projects; the study established that motivation will be a challenge when firms fail to support their workers. Doloi [16] researched motivation amongst construction artisans. He established that providing motivation requires acknowledging the significance of job output to the performance at the end of the project. Jilang [17] investigated female artisans and professionals in construction industry and discovered that construction projects are inherently gratifying. $\mathrm{Ng}$ et al. [18] examined how civil engineers demotivate at construction site in Hong Kong and discovered that what was demotivating is unavailability of materials, full work areas and rework. A study by [19] investigated motivation amongst Australian project managers and found that generally the size of project had no link with motivation. Smithers \& Walker [20] examined the impact of the construction site environment on motivation and demotivation and revealed that at construction site working long hours, poor planning and uneven resource allocation influence demotivation levels of construction site workers. Little or no literature in Ghana has highlighted the strategies for motivating construction craftsmen; it is against this background the study is conducted to fill this gap. The survey aims to assess motivational strategies to improve performance of artisans in construction firms. In the quest 
to deal with the issues of motivational strategies the following objectives will be pursued by the study:

- To determine the association amid empowerment and motivation

- To examine the association between learning and motivation

- To analyse the relationship between monetary incentive and motivation

- To examine the association between quality of life and motivation The hypotheses developed for the study are:

- H1: Empowerment has a significant association with motivation

- H2: Learning has a significant relationship with motivation

- H3: Monetary incentive has a significant association with motivation

- H4: Quality of life has a significant association with motivation

\subsection{Overview of Abraham Maslow, Hierarchy Needs Theory}

There is an enormous number of motivational theories that have been employed to describe motivational factors that impact the motivation of workers. Theories of work motivation usually comprised both personality and situational traits [21]. Dwivedula and Bredillet [8] categorise motivation for workers as content-based and process-based theories. This categorisation was recognised by [4], who explain motivation as one directed towards motivating individuals, such as construction operatives whereas the process-based theories draw attention to motivation of operators. Abraham Maslow as one of the founders within the work motivation domain developed, well-known Needs Hierarchy Theory in 1943; The Maslow hierarchy needs theory has been a source of motivation for organisations and construction industry is no exception. Founded on Maslow's theory, Schrader [22] anticipated a need for construction staff (artisans) motivation and recognised suitable methods that can address motivational issues. Hazeltine [23] proposed that the lower level needs are typically satisfied and the higher-level needs necessitate consideration. He encouraged that motivation can be utilised to accomplish the higher-level needs of construction workers (artisans). Shoura and Singh [24] highlighted the significance of self-development to satisfy the self-actualization requirement for construction engineers.

\subsection{The Overview of Ghanaian Construction Industry}

The construction industry in Ghana seems to be doing well, and indeed contributes significantly to gross domestic product (GDP) in Ghanaian economy and significantly employs good number of people to the economy. Ofori [25] informed that construction accounted for 7.2\% of GDP in 2018 physical year. Again Ofori [25] posited that 584,513 peoples involve in construction, and out of that 316,368 peoples were employed, whereas those employed 309,312 gain their employment in informal sector. Moreover, Ofori [25] opines that 101,154 Apprentices are engaged in Ghanaian construction. The report from Ghana Statistical Service (GSS), was that amid 2009 and 2013, the construction and real estate industry accounted for 14.34 per cent to the country's GDP [26]. Ghanaian 
construction industry appears to be one of the major employers in the economy as compare to number of people in the industry. The trend of growth rate of construction to GDP is accelerating from 2006 to 2016. The report of GSS [26] (2018) indicated that the growth rate of construction industry to GDP has been more than double, thus $5.7 \%$ and $13.7 \%$ in 2006 and 2016 respectively. The construction industry in Ghana is multifaceted in nature, since it involves various stakeholders [27] such as Ghana Institute of Construction (GIOC), Ghana Institution of Architects (GIA), Ghana Real-Estate Development Agency (GREDA), Ghana Institution of Engineers (GhIE) and Ghana Institution of Surveyors (GhIS). Also, the Ministry of Water Resources, Works and Housing, and Ministry of Road and Highways are responsible for housing and road respectively. However, other departments that play a tremendous role in Ghanaian construction industry are Architectural \& Engineering Services Limited (AESL), Metropolitan, Municipal and District Authorities (MMDAs), Department of Feeder Roads, Department of Urban Roads, Ghana Highway Authority, Ghana Building contractors Association, Ghana Road contractors Association etc. all these bodies make management of construction complex. The challenges to Ghanaians construction industry cannot be underestimated. According to [28] challenges to construction sector in Ghana include planning deficiency, unsuitable water and energy use, building material consumption, not able to meet consumer/tenant requirements, and fragmented stakeholders' cooperation in the industry. However, in the opinion of [29] all these challenges are the reasons for corruption and untransparent procurement procedures with regard to hiring services of consultants and contractors. Further, [30] opine that the continuous degradation of the environment has impacted the development in Ghana and has resulted in building construction procedures unsustainable. According to [31] the number of challenges recognised as impacting the various construction organisation involves difficulty in accessing sufficient fund to execute project, inadequate management deficiency, deficient in engineering competence and poor workmanship. Whereas Badu, Edwards and Owusu-Manu [32] acknowledge that available debt financing arrangement for large and small construction firms comes with very high interest rate and these are the leading causes of project abandonment. Adu Gyamfi et al. [33] discovered that delays in payments, under-budgeting, freeze in capital, bankruptcy of stakeholders, and corruption as financial challenges associated to public and private project.

\subsection{Motivation Strategies for Productivity}

The association between motivation and productivity is briefly described as a direct relationship amid motivation, and productivity. Motivation is, related to productivity. The proper motivation of craftsman can be assumed as a significant factor to enhance employees' productivity, and employee's performance in various institutions can be influenced mainly by motivation [34]. As opined by [35], numerous approaches of motivating employees exist as compared with dif- 
ferent firms, establishments, organisations etc. working in the surroundings worldwide. There are common measures frequently used across all organisations to improve workers motivation. Strategies such as creativity and innovation, learning, empowerment, monetary incentive, quality of life and rewards are considered as measures to increase productivity. In the view of Woodman et al. [36] novelty and creativity are vital for organisational success and make organisations more competitive above their competitors. A commonly recognised explanation argues that creativity is producing new and valuable concepts, whereas innovation is the effective application of creative concepts in a society [37]. Gumusluoglu, and Ilsev [38] in their study found that creativity and innovation are vital in that it can contribute to identifying transformational leaders in organisations. Amabile [37] posits that creative ideas will be required not necessary for the development of novel, valuable products and services, but also the resolution of ever-changing and ever more mystifying business difficulties. Diliello \& Houghton [39] predict that a great self-leader with high-level creative capacity, are always eager to apply creativity and innovations in their environment than a weak self-leader. Aghayar, [40] opined that the advantages of empowerment could be increasing of profit and quality satisfaction of the customer, feeling of belonging and ownership of personnel to the organisation, improvement of job's condition and reduction of expenses, wastages, nervous pressure, accidents and direct control of the supervisor. Empowering workers to meet customer requirements or resolving problems related services are considered the best ways to satisfy customers to perform well in their workplace [41]. According to Spreitzer [42] empowerment offer workers the opportunity to make a decision and discretionary power over how they perform their work. Light [43] in her $\mathrm{PhD}$ dissertation found that personnel empowerment influences on job's satisfaction, whenever their empowerment becomes more, their job's satisfaction becomes more [44]. Bonner et al. [45] said, financial incentives influence workers to set targets when they have not thought of it, financial incentives may perhaps influence workers to set more demanding targets they have not thought of it; these targets, requires putting in much effort to attain the goals. Finally, financial incentives schemes might lead to higher commitment in setting targets as compare with non-incentive schemes [45]. Delfgaauw \& Dur, [46] in their opinion when competition in organisations become high; employees had opportunities to decide on which agency they will attach themselves, owing to stronger incentives, idle workers are influenced to work harder in the public sector organisation, when they are aware that their remuneration is tied to their performance. Again, they opine that monetary incentives are not a motivator for the effort of the public worker, is a significant motivator to the effort in the private condition. According to Ariely, Bracha, \& Meier, [47] monetary incentive depends significantly on what the workers see being implemented on incentives: financial incentives are more effective in expediating private, prosocial activities than public. The implication is that financial incentives as motivation promote workers prosocially. 


\section{Methodology}

This research utilized a two-stage method to the study. The first stage was reviewing of literature which assisted in determining a variable for measuring artisans' motivation in Ghanaian construction industry. The second stage was the utilisation of quantitative approach (questionnaire). As posited by Creswell, and Creswell [48] quantitative enquiry is a technique for examining objective theories by evaluating the association amid study indicators. These indicators, by another approach, is determined, generally by mechanisms, in away quantitative data can be examined utilizing statistical processes techniques. Quantitative analysis by Babbie [49] is the numerical representation and maneuvering of observations to describe and explaining the phenomenon that those observations reflect. The current study employs descriptive survey to allow the gathering of quantitative data and also enabled the use of quantitative methods in the analysis of data.

The study population comprised of 20 construction companies targeted from Greater Accra and Eastern regions of Ghana. Ten (10) employees each from the twenty (20) construction companies were targeted totaling two hundred employees (200). Purposive sampling was used to enable the researcher to focus on the skilled craft employees. These professionals are knowledgeable in their areas of expertise. Purposive sampling was applied to choose hundred (100) employees from the various companies working in the construction site; the 100 employees sampled represent $50 \%$ of the target population. In the Greater Accra region, ten (10) construction companies were selected with five (5) employees from each of the companies, totaling 50 respondents. In the Eastern region, ten (10) construction companies were selected with five (5) employees from each of the ten companies, totaling 50 respondents. According to De Looff [50], a sample size of more than $10 \%$ of the population is enough for a credible empirical research.

The questionnaires were employed to collect data. The questionnaire was distributed to the 100 employees, out of which 90 were returned. This gives a response rate of $90 \%$. Five-point Likert scales were used ranging from 1 to 5, thus strongly disagree to strongly agree. The validity of the study was achieved by ensuring that the questionnaires reflect the content of the literature review and correction of ambiguous items. The reliability of the study was achieved by obtaining Cronbach's coefficient alpha of 0.817 where Nunally and Bernstein [51] and Du Plessis [52] accepted as good fit. The Statistical Package for Social Sciences (SPSS), version 20 and Smart Partial Least Squares Structural Equation Modeling (PLS-SEM) 3.0 were employed to analyse the data.

\section{Results of the Study}

\subsection{Demographic Characteristics of Respondents}

The analysis of the demographic characteristics looked at respondents' position held in the company, number of working experiences in the industry, age group 
and level of educational qualification. Table 1 presents results on the position held by respondents in the company.

Respondents specify how long they have worked in the industry. Their responses are presented in Table 2.

The findings revealed that the major part of the artisans had spent more than 6 years in the organisation. This revelation is in line with Aguinis [53] assertion that the longer you work in organisation the more you gain experience to perform task better. Perhaps one of the reasons could be due to the level of motivation in the organisation.

\subsection{Factors Influence Artisans' Motivation}

The study sought to determine the key factors that influence artisans' motivation at the construction workplace. Table 3 indicates the results of motivational strategies that can be employed by construction industry practitioners to motivate artisans.

\subsection{Data Analysis Using PLS-SEM}

Smart PLS is one of the structural equation models (SEM) that, provides an explanation to association existing between multiple research items concurrently and further predicts the relationship among dependent and independent variables employed in the analysis. In the opinion of Gefen et al. [54] SEM has an exceptional benefit over linear regression; thus, SEM provides an opportunity to create an estimated model of many dependent variables and their interrelationship simultaneously. Again, the benefit of SEM over linear regression is that it

Table 1. Position held in the company.

\begin{tabular}{ccc}
\hline Position & Frequency & Percentage (\%) \\
Carpenters & 17 & 18.88 \\
Masons & 29 & 32.23 \\
Plumbers & 15 & 16.66 \\
Electricians & 13 & 14.45 \\
Steel benders & 16 & 17.78 \\
Total & 90 & 100.0
\end{tabular}

Source: Researchers' Field survey (2020).

Table 2. Years of working experience.

\begin{tabular}{ccc}
\hline Working experience & Frequency & Percentage (\%) \\
\hline $1-5$ years & 27 & 30.0 \\
6 - 10 years & 50 & 55.55 \\
$11-15$ years & 13 & 14.45 \\
Total & 90 & 100.0 \\
\hline
\end{tabular}

Source: Researchers' Field survey (2020). 
Table 3. Descriptive statistics on motivational factors affect $(\mathrm{N}=90)$.

\begin{tabular}{|c|c|c|c|c|c|}
\hline CODE & Factor impacting artisan motivation & Min. & Max. & Mean St & td. Deviation \\
\hline EMP & \multicolumn{5}{|c|}{ Empowerment } \\
\hline EMP1 & More decision-making authority & 2.00 & 5.00 & 3.9643 & 0.72544 \\
\hline EMP2 & More responsibility & 2.00 & 5.00 & 4.0294 & 0.74306 \\
\hline EMP3 & $\begin{array}{l}\text { Providing adequate time and material } \\
\text { resources to carry out a task }\end{array}$ & 2.00 & 5.00 & 4.1286 & 0.77024 \\
\hline LENG & \multicolumn{5}{|c|}{ Learning } \\
\hline LENG1 & On the job training & 2.00 & 5.00 & 3.9714 & 0.69866 \\
\hline LENG2 & Study leave & 3.00 & 5.00 & 4.3429 & 0.51122 \\
\hline LENG3 & Capacity building & 3.00 & 5.00 & 4.3571 & 0.60417 \\
\hline QUAOL & \multicolumn{5}{|c|}{ Quality of life } \\
\hline QUAOL1 & Improved working conditions & 3.00 & 5.00 & 4.2571 & 0.70054 \\
\hline QUAOL2 & Good Administrative policy & 3.00 & 5.00 & 4.2643 & 0.57823 \\
\hline QUAOL2 & Good work relationship & 3.00 & 5.00 & 4.3714 & 0.50502 \\
\hline QUAOL3 & Proper communication & 3.00 & 5.00 & 4.4714 & 0.51009 \\
\hline QUAOL4 & Job Security & 3.00 & 5.00 & 4.2786 & 0.56155 \\
\hline MOINTV & \multicolumn{5}{|c|}{ Monetary Incentive } \\
\hline MOINTV1 & Salary paid on time or before time & 3.00 & 5.00 & 3.9786 & 0.39932 \\
\hline MOINTV2 & Pay Salary increment on time & 3.00 & 5.00 & 4.3857 & 0.50126 \\
\hline MOINTV3 & Good salary & 3.00 & 5.00 & 4.3214 & 0.55761 \\
\hline MOINTV4 & Fringe Benefits (Allowance) & 3.00 & 5.00 & 4.2786 & 0.61468 \\
\hline
\end{tabular}

Source: Researchers' Field survey (2020).

offers better results in path diagram analysis when multiple latent variables indicators are considered [54]. PLS-SEM is gaining popularity as numerous studies have been extensively employed PLS-SEM in social science disciplines, such as strategic management, supply chain management, operations management, human resource management, hospitality management, organisational management, information systems management, management of marketing, and accounting management [55]-[63]. Some of the researchers study workers' motivation and performance in their various thematic areas and since the current study investigates the strategies for motivating artisans' performance in building construction industry, the study adopts PLS-SEM to model the situation under consideration. Also, the study employs PLS-SEM because the structural model is complex and consists of many constructs, observed variables and model correlation, and application of small sample size [64]. The current study focused on how the various construct such as empowerment, qualify of life, learning and monetary incentive influences the dependent variable motivation as regards the construction operatives (Artisans). Moreover, PLS-SEM has user friendly inter- 
face and easy to work with [65] [66]. PLS SEM is described as a method most appropriate where the study intention is prediction or exploratory modeling. Whiles, covariance-based SEM is chosen when the study aim is confirmatory modeling [67].

Since the various observed variables are measuring the individual construct and the constructs are also determining their relationship with the dependent variable (motivation), these situations require a robust statistical tool to analyse these relationships, hence the application of Smart PLS-SEM. According to Gerbing and Anderson [68] for the construct to be analysed by PLS-SEM two essential procedures must be followed, thus the determination of path and measurement model. The path coefficient is used to predict the association between the dependent and independent variables. Chin [69] hypothesized that path coefficients and the $\mathrm{R}^{2}$ are both employs to evaluate the model whereas the error estimates and t-values are applied to determined associations. The path coefficient is also used to test the hypothesis of the study. Table 6 signifies that t-values above 1.9 were all significant. The t-value for hypothesis $\mathrm{H} 1, \mathrm{H} 3$ and $\mathrm{H} 4$ were statistically significant with t-value as $1.948,2.724$ and 1.958 and p-value $0.052,0.007$ and 0.052 respectively. The t-statistic for $\mathrm{H} 1, \mathrm{H} 3$, and $\mathrm{H} 4$ support the study hypothesis as a strong association between study construct empowerment, quality of life, a monetary incentive and motivation. The observed indicators are used to determine the reliability and validity of the construct.

According to Hair et al. [70] reliability is the degree where a study produces the same results when applied in different situations. The type of reliability used for the survey was Cronbach alpha and Composite Reliability (CR) as revealed in Table 4, the study produces Cronbach alpha values between 0.759 to 0.876 which is acceptable good fit as recommended by [71]. According to Koufteros, [71] the CR represent a set of possible observe variables that share in their measurement of a construct. Diamantopoulos et al., [72] and Hair et al. [73] (2010:710) posited that a CR bigger than 0.60 is considered as the desired value, CR of 0.70

Table 4. Accurate statistic.

\begin{tabular}{|c|c|c|c|c|c|c|}
\hline Construct & & $\begin{array}{l}\text { R-Square } \\
\text { value }\end{array}$ & $\begin{array}{l}\text { Cronbach } \\
\text { Alpha }\end{array}$ & $\begin{array}{l}\text { Composite } \\
\text { Reliability }\end{array}$ & $\begin{array}{c}\text { Average variance } \\
\text { Extracted }\end{array}$ & $\begin{array}{c}\text { Factor } \\
\text { loadings }\end{array}$ \\
\hline \multirow[t]{2}{*}{ Empowerment } & Q7B & 0.00 & 0.759 & 0.753 & 0.543 & 0.704 \\
\hline & Q7C & & & & & 0.769 \\
\hline \multirow[t]{3}{*}{ Learning } & Q9A & 0.00 & 0.787 & 0.704 & 0.625 & 0.640 \\
\hline & Q9B & & & & & 0.901 \\
\hline & Q9C & & & & & 0.807 \\
\hline \multirow[t]{2}{*}{ Quality of life } & Q10C & 0.00 & 0.845 & 0.830 & 0.622 & 0.543 \\
\hline & Q10D & & & & & 0.975 \\
\hline \multirow[t]{2}{*}{ Monetary incentives } & Q11B & 0.00 & 0.876 & 0.729 & 0.588 & 0.925 \\
\hline & Q11C & & & & & 0.566 \\
\hline Motivation & Q5 & 0.143 & & 1.00 & 1.00 & \\
\hline
\end{tabular}


or higher stipulates strong composite reliability. Ning [74] stated that higher CR values show strong latent reliabilities, indicating an acceptable internal reliability from variable of each construct. The $\mathrm{CR}$ values of the study ranged from 0.704 to 1.00 as reported in Table 4 . The study employed convergent and discriminant validity. The convergent validity is the degree of connection amid two different sources answering to the same measure. However, discriminant validity is the amount to which means of different latent variables are unmatched [75] [76]. Convergent validity is determined by considering the average variance extracted (AVE) and factor loadings of the construct variables. The AVE value of 0.5 or more is significant and factor loading of 0.5 or more is significant, indicating higher convergent validity [73] [74] [77]. From Table 4 AVE value ranges from $0.534-1.00$, whereas factor loadings range from $0.534-0.975$ indicating higher convergent validity for the study construct variables. However, the determination of discriminant validity can be achieved by using Fornell and Larcker [77] recommendation, that square root of AVE in each construct latent variable are employed to determine discriminant validity, when the value under consideration is more significant than other associated values amid the latent indicators. It can be observed from Table 4, that the lowest AVE value for construct latent variables is 0.534 when this value is squared base on the recommendation of Fornell and Larcker [74] (1981) the calculated results will be 0.731. The estimated value is higher than the correlated value obtained among the latent variables as indicated in Table 5. The result shows that the study has achieved strong discriminant validity. The reasons for such higher correlation are due to strong relationship among the constructs.

\subsection{Discussion of the Study}

The study hypothesis (H1) theorized that there is an association between empowerment and motivation. The result is indicated in Table 6, and Figure 1 supported the study hypothesis with $\mathrm{p}<0.052$ and path coefficient of -0.165 . The results show that empowering skilled craftsman in the construction site motivated them to perform adequately in their various work environments. The findings are in line with Chiang \& Jang [41] (2008). They posited that empowering workers

Table 5. Correlation matrixes for interrelations of a construct to check discriminant validity.

\begin{tabular}{cccccc}
\hline Construct & EMP & LENG & MOINTV & MOT & QUAOL \\
\hline EMP & 0.737 & & & & \\
LENG & 0.695 & 0.790 & & & \\
MOINTV & 0.676 & 0.654 & 0.767 & & \\
MOT & 0.660 & 0.642 & 0.599 & 1.00 & \\
QUAOL & 0.650 & 0.643 & 0.550 & 0.569 & 0.789 \\
\hline
\end{tabular}

Note: $\mathrm{EMP}=$ Empowerment, $\mathrm{LENG}=$ Learning, $\mathrm{MOINTV}=$ Monetary Incentive, $\mathrm{MOT}=$ Motivation, QUAOL $=$ Quality of life. 
Table 6. Hypothesis model analyses.

\begin{tabular}{cccccc}
\hline Study Hypothesis & $\begin{array}{c}\text { Hypothesis } \\
\text { outcome }\end{array}$ & $\begin{array}{c}\text { Path } \\
\text { coefficients }\end{array}$ & T-Statistic & P-value & Support/Rejected \\
\hline EMP-MOT & $\mathrm{H} 1$ & -0.165 & 1.948 & $0.052^{*}$ & Supported \\
LENG-MOT & $\mathrm{H} 2$ & 0.170 & 1.263 & 0.207 & Rejected \\
MOINTV-MOT & $\mathrm{H} 3$ & -0.175 & 2.724 & $0.007^{*}$ & Supported \\
QUAOL-MOT & $\mathrm{H} 4$ & -0.256 & 1.958 & $0.051^{*}$ & Supported \\
\hline
\end{tabular}

Note: $\mathrm{p}<0.05$.

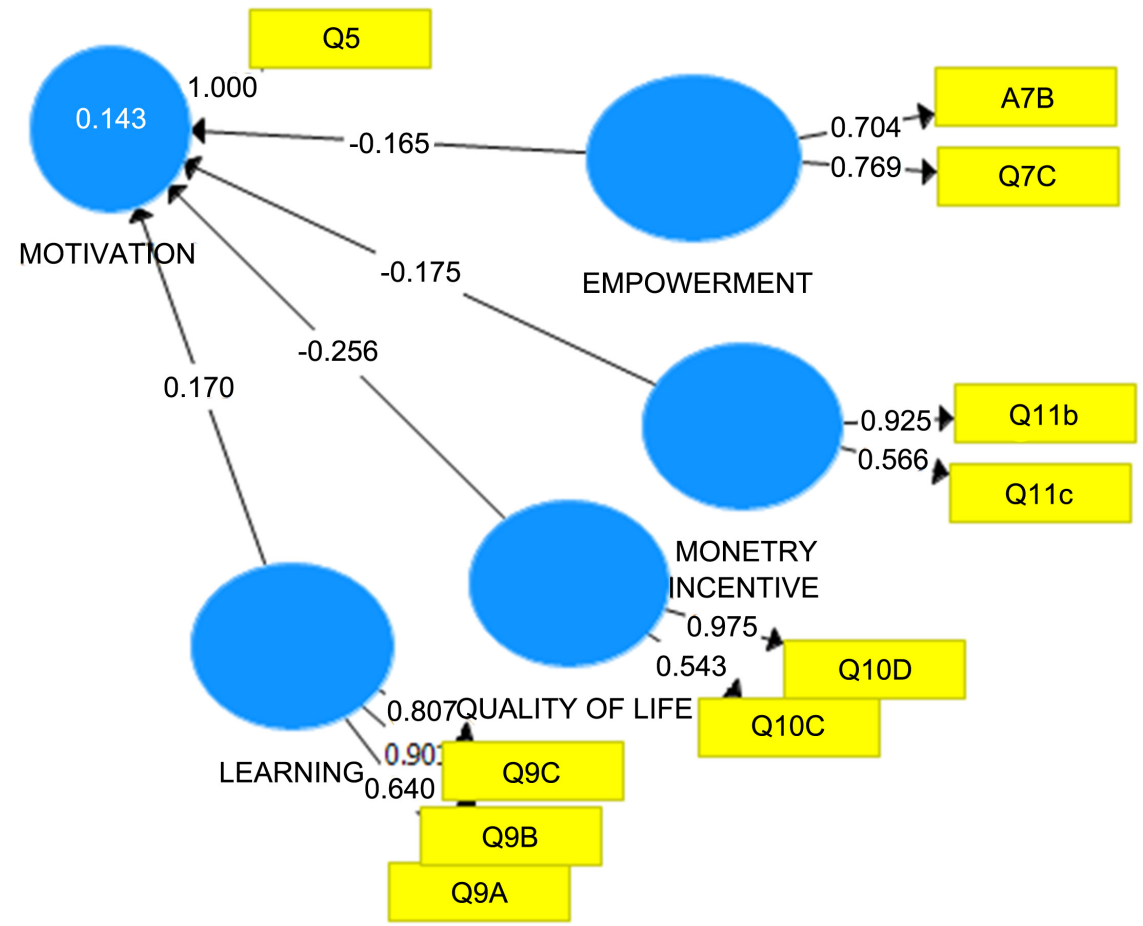

Figure 1. Structural model of the study.

to meet customer requirements or resolving problems related services are considered the best ways to satisfy customers. According to Spreitzer [42] (1995) empowerment offers workers the opportunity to make a decision and discretionary power over how they perform their work. Light [43] (2004) showed that personnel empowerment influences on job's satisfaction. Whenever empowerment becomes more, their job's achievement becomes more [44] (Shelton, 2002).

The study hypothesis (H3) posited that there exists a significant correlation amid monetary incentive and workers' motivation. The result is shown in Table 6 and Figure 1 supported the study hypothesis with $\mathrm{p}<0.007$ and path coefficient of -0.175 . The result indicates that providing a monetary incentive to artisans in the construction industry motivated them to function effectively in their work environment. Bonner et al. [45] (2002) said, financial incentives may perhaps influence workers to set more demanding targets they have not thought of it; these targets, requires putting in much effort to attain the goals. Delfgaauw \& 
Dur [46] (2004) in their opinion believed that when competition in organisations becomes high, employees had opportunities to decide on which agency they will attach themselves, due to stronger incentives. According to Ariely, Bracha, \& Meier, [41] (2007) monetary incentive depends significantly on how workers experience its implementation: financial incentives are more effective in enabling private, prosocial activity than public. The study hypothesis ( $\mathrm{H} 4)$ hypothesised that there is a significant association amid quality of life and employee's motivation. The result shown in Table 6 and Figure 1 supported the study hypothesis with $\mathrm{p}<0.051$ and path coefficient of -0.256 . The result informs that ensuring quality of life among artisan in construction industry will motivate them to perform efficiently in their work environment.

\section{Conclusion}

The purpose of the study is to investigate motivational strategies to improve the performance of artisans in construction companies. Four hypotheses were developed. To test these hypotheses, data were gathered from artisans in construction companies in the Greater Accra and Eastern regions in Ghana. The study hypotheses that H1: Empowerment has a significant association with motivation, H2: Learning has a significant relationship with motivation, H3: Monetary incentive has a significant relationship with motivation, H4: Quality of life has a significant association with motivation. The empirical results supported three of the hypotheses and rejected one of the hypotheses. It was revealed from the study that empowerment, a monetary incentive and quality of life had a significant relation with motivation. This implies that motivation could be effective to improve the performance of artisans in the construction industry if site managers, supervisors and engineers employ the identify strategies in their organisations.

\section{Recommendations}

- The study recommends that construction manager should incorporate motivational measures in their human resource planning since motivation has the potential of increasing productivity in the organisation.

- Managements are also required to improve the quality of life of its employees (artisans). This can be achieved by providing good working conditions such as accommodation, good salary, pay increments etc.

- The study has revealed that promotion is a major motivation factor that affects employees' (artisans) performance. The study recommended that the construction organisations should review and amend guidelines on promotions to inspire workers (artisans) who have constantly performed or served better in their organisations.

\section{Conflicts of Interest}

The authors declare no conflicts of interest regarding the publication of this paper. 


\section{References}

[1] Kpamma, E.Z. (2009) The Practice of Lean Thinking at the Pre-Contract Stage of Building Construction Projects by Selected Ghanaian Firms. Unpublished MSc Thesis, Kwame Nkrumah University of Science and Technology, Kumasi.

[2] Alinaitwe, H.M. (2009) Prioritizing Lean Construction Barriers in Uganda's Construction Industry. Journal of Construction in Developing Countries, 14, 15-30.

[3] Yankov, L. and Kleiner, B.H. (2001) Human Resources Issues in the Construction Industry. Management Research News, 24, 101-105. https://doi.org/10.1108/01409170110782711

[4] Arnold, J. and Schoonman, W. (2002) Maintaining and Enhancing Motivation as a Contribution to Organizational Effectiveness. In: Robertson, I.T., Callinan, M. and Bartram, D., Eds., Organizational Effectiveness: The Role of Psychology, John Wiley \& Sons, Ltd., Chichester, 159-180. https://doi.org/10.1002/9780470696736.ch7

[5] Hughes, R.L., Ginett, R.C. and Curphy, G. J. (2009) Leadership: Enhancing the Lessons of Experience. 6th Edition, McGraw-Hill/Irwin, New York, 368-436.

[6] Latham, G.P. and Ernst, C.T. (2006) Keys to Motivating Tomorrow's Workforce. Human Resource Management Review, 16, 181-198.

https://doi.org/10.1016/j.hrmr.2006.03.014

[7] Whitmore, J. (2009) Coaching for Performance. 4th Edition, Nicholas Brealey Publishing, London, 106-111.

[8] Dwivedula, R. and Bredillet, C.N. (2010) Profiling Work Motivation of Project Workers. International Journal of Project Management, 28, 158-165. https://doi.org/10.1016/j.ijproman.2009.09.001

[9] Project Management Institute (2008) A Guide to the Project Management Body of Knowledge. 4th Edition, Project Management Institute, Newtown Square, 22-32, 215-242, 417-420.

[10] Currie (1972) Employee Motivation: Motivation in the Workplace-Theory and Practice. http://www.accel-team.com/productivity/addedValue

[11] Asare-Bediako, K. (2002) Professional Skills in Human Resource Management. Kasbed Ltd., Accra.

[12] Amadi, A.O. (1991) Recipe for Productivity Improvement. Proceedings of the First National Conference on Productivity, Macmillan, 1-3 December 1987, 98-106.

[13] Emery, R.C. (2009) A Cause-Effect-Cause Model for Sustaining Cross-Functional Integration. Business Process Management Journal, 15, 93-108.

https://doi.org/10.1108/14637150910931488

[14] Shadare, O.A. and Ayo, H.T. (2000) Influence of Work Motivation, Leadership Effectiveness and Time Management of Employees Performance in Some Selected Industries in Ibadan, Oyo State, Nigeria. European Journal of Economics, Finance and Administrative Science, 16, 7-17

[15] Cox, R.F., Issa, R.R.A and Frey, A. (2006) Proposed Subcontractor-Based Employee Motivational Model. Journal of Construction Engineering and Management, 132, 152-163. https://doi.org/10.1061/(ASCE)0733-9364(2006)132:2(152)

[16] Doloi, H (2007) Twinning Motivation, Productivity and Management Strategy in Construction Projects. Journal of Engineering Management, 19, 30-40. https://doi.org/10.1080/10429247.2007.11431738

[17] Jiliang, D. (2005) Motivation of Construction Engineers in Yunnan, China, Thesis (M. Eng.), Asian Institute of Technology, Pathum Thani. 
[18] Ng, S.T., Skitmore, R.M., Lam, K.C., and Poon, A.W. (2004) Demotivating Factors Influencing the Productivity of Civil Engineering Projects. International Journal of Project Management, 22, 139-146. https://doi.org/10.1016/S0263-7863(03)00061-9

[19] Chan, A.P.C. (2003) Motivation of the Project Manager. Proceedings of CIB W65, Trinidad, 15-22 September 2003, 931-942.

[20] Smithers, G.L. and Walker, D.H.T. (2000) The Effect of the Workplace on Motivation and Demotivation of Construction Professionals. Construction Management and Economics, 18, 833-841. https://doi.org/10.1080/014461900433113

[21] Erez, M. and Eden, D. (2001). Introduction-Trends Reflected in Work Motivation in the Context of a Globalizing Economy. Lawrence Erlbaum Associates, Inc., New Jersey, 1-8.

[22] Schrader, C.R. (1972) Motivating Construction Craftsmen. Journal of the Construction Division, 98, 257-273.

[23] Hazeltine, C.S. (1976) Motivation of Construction Workers. Journal of the Construction Division, 102, 497-509.

[24] Shoura, M.M. and Singh, A. (1998) Motivation Parameters for Engineering Managers Using Maslow's Theory. Journal of Management and Engineering, 15, 44-55. https://doi.org/10.1061/(ASCE)0742-597X(1999)15:5(44)

[25] Ofori, G. (2018) Ghana's Construction Industry, Yesterday, Today and Tomorrow: Towards Greater Professionalism: Maiden Annual Construction Industry Lecture. International Conference Centre, Accra.

[26] Ghana Statistical Services (2018) National Accounts. http://www.statsghana.gov.gh/

[27] Dadzie, J., Abdul-Aziz, and Kwame, A. (2012) Performance of Consultants on Government Projects in Ghana: Client and Contractor Perspective. International Journal of Business and Social Research, 2, 256-267.

[28] Twumasi-Ampofo, K., Osei-Tutu, E., Decardi-Nelson, I. and Ofori, P.A. (2013) A Model for Reactivating Abandoned Public Housing Projects in Ghana. Civil and Environmental Research, 6, 6-16.

[29] Asamoah, R.O. and Decardi-Nelson, I. (2014) Promoting Trust and Confidence in the Construction Industry in Ghana through the Development and Enforcement of Ethics. Information and Knowledge Management, 4, 63-68.

[30] Djokoto, S., John, D. and Ohemeng-Ababio, E. (2014) Barriers to Sustainable Construction in the Ghanaian Construction Industry: Consultants' Perspective. Journal of Sustainable Development, 7, 134-143. https://doi.org/10.5539/jsd.v7n1p134

[31] Ofori, G. (2012) Developing the Construction Industry in Ghana: The Case for a Central Agency. National University of Singapore, Kent Ridge.

[32] Badu, E., Edwards, P. and Owusu-Manu, D. (2012) Trade Credit and Supply Chain Delivery in the Ghanaian Construction Industry: Analysis of Vendor Interactions with Small to Medium Enterprises. Journal of Engineering, Design and Technology, 10, 360-379. https://doi.org/10.1108/17260531211274729

[33] Adu Gyamfil, T., Pratt, I. and Nana-Addy, E. (2018) Assessing the Effect of Risk on Public and Private Construction Projects Performance in Ghana: Consultant Perspective. International Journal of Construction Engineering and Management, 7, 185-192.

[34] Kazaz, A., Manisali, E. and Ulubeyli, S. (2008) Effect of Basic Motivational Factors on Construction Workforce Productivity in Turkey. Journal of Civil Engineering and Management, 14, 95-106. https://doi.org/10.3846/1392-3730.2008.14.4

[35] Coates, J.F. and Jennifer, J. (2004) Construction Work Place Creativity: Employ- 
ment Relation Today. Spring. Construction Projects. International Journal of Project Management, 32, 52-69.

[36] Woodman, R.W., Sawyer, J.E. and Griffin, R.W (1993) Toward a Theory of Organizational Creativity. Academy of Management Review, 18, 293-321.

https://doi.org/10.2307/258761

[37] Amabile, T.M. (1996) The Motivation for Creativity in Organisations. 9-396-240, Harvard Business School, Boston.

[38] Gumusluoglu, L. and Ilsev, A. (2009) Transformational Leadership, Creativity, and Organizational Innovation. Journal of Business Research, 62, 461-473.

https://doi.org/10.1016/j.jbusres.2007.07.032

[39] DiLiello, T.C. and Houghton, J.D. (2006) Maximizing Organizational Leadership Capacity for the Future: Toward a Model of Self-Leadership, Innovation and Creativity. Journal of Managerial Psychology, 21, 319-337. https://doi.org/10.1108/02683940610663114

[40] Aghayar, S. (2003) Designing and Explaining the Pattern of Managers of Caravan Empowerment, Hajj and Charitable Bequests. PhD Dissertation of Management of Human Sources' Field, Tehran University, Tehran.

[41] Chiang, C.-F. and Jang, S.C.S. (2008) An Expectancy Theory Model for Hotel Employee Motivation. International Journal of Hospitality Management, 27, 313-322. https://doi.org/10.1016/j.ijhm.2007.07.017

[42] Spreitzer, G.M. (1995) Psychological Empowerment in the Workplace: Dimensions, Measurement, and Validation. Academy of Management Journal, 38, 1442-1465. https://doi.org/10.5465/256865

[43] Light, J.N. (2004) The Relationships and Effects of Employee Involvement, Employee Empowerment and Employee Satisfaction by Job Type in Large Manufacturing Environment. Ph.D. Dissertation, Capella University, Minneapolis.

[44] Shelton, S.T. (2002) Employee, Supervisors and Empowerment in the Public Sector: The Role of Employee Trust. Ph.D. Dissertation, North Carolina State University, Raleigh.

[45] Bonner, S.E. and Sprinkle, G.B. (2002) The Effects of Monetary Incentives on Effort and Task Performance: Theories, Evidence, and a Framework for Research. Accounting, Organizations and Society, 27, 303-345. https://doi.org/10.1016/S0361-3682(01)00052-6

[46] Delfgaauw, J. and Dur, R. (2004) Incentives and Workers' Motivation in the Public Sector. Tinbergen Institute Discussion Paper No. 04-060/1, Tinbergen Institute, Amsterdam and Rotterdam. http://dx.doi.org/10.2139/ssrn.555062

[47] Ariely, D., Bracha, A. and Meier, S. (2007) Doing Good or Doing Well? Image Motivation and Monetary Incentives in Behaving Prosocially. No. 2968, Institute for the Study of Labor, Bonn.

[48] Creswell, J.W. and Creswell, J.D. (2018) Research Design: Qualitative, Quantitative, and Mixed Methods Approaches. Sage, Los Angeles.

[49] Babbie, E. (2005) The Basics of Social Research. Thomson/Wadsworth, Belmont.

[50] De looff, L.A. (1996) Information Systems Outsourcing Decision Making: A Managerial Approach. IGI Publishing, Hershey.

[51] Nunnally, J.C. and Bernstein, I.H. (1994) Psychometric Theory. 3rd Edition, McGraw-Hill, New York, 286-297.

[52] Du Plessis, L. (2010) Customer Relationship Management and Its Influence on Customer Loyalty at Liberty Life in South Africa. University of Johannesburg, Jo- 
hannesburg.

[53] Aguinis, H. (2009) Performance Management. 2nd Edition, Prentice Hall/Pearson Education, Upper Saddle River, London.

[54] Gefen, D., Rigdon, E.E. and Detmar, S. (2011) Editor's Comments: An Update and Extension to SEM Guidelines for Administrative and Social Science Research. MIS Quarterly, 35, iii-xiv. https://doi.org/10.2307/23044042

[55] Hair, J.F., Sarstedt, M., Pieper, T.M. and Ringle, C.M. (2012a) The Use of Partial Least Squares Structural Equation Modeling in Strategic Management Research: A Review of Past Practices and Recommendations for Future Applications. Long Range Planning, 45, 320-340. https://doi.org/10.1016/j.lrp.2012.09.008

[56] Kaufmann, L. and Gaeckler, J. (2015) A Structured Review of Partial Least Squares in Supply Chain Management Research. Journal of Purchasing and Supply Management, 21, 259-272. https://doi.org/10.1016/j.pursup.2015.04.005

[57] Peng, D.X.S. and Lai, F.J. (2012) Using Partial Least Squares in Operations Management Research: A Practical Guideline and Summary of Past Research. Journal of Operations Management, 30, 467-480.

[58] Ringle, C.M., Sarstedt, M., Mitchell, R. and Gudergan, S.P. (2019) Partial Least Squares Structural Equation Modeling in HRM Research. The International Journal of Human Resource Management, 31, 1617-1643. https://doi.org/10.1080/09585192.2017.1416655

[59] Ali, F., Rasoolimanesh, S.M., Sarstedt, M., Ringle, C.M. and Ryu, K. (2018) An Assessment of the Use of Partial Least Squares Structural Equation Modeling (PLS-SEM) in Hospitality Research. International Journal of Contemporary Hospitality Management, 30, 514-538. https://doi.org/10.1108/IJCHM-10-2016-0568

[60] Sosik, J.J., Kahai, S.S. and Piovoso, M.J. (2009) Silver Bullet or Voodoo Statistics? A Primer for Using the Partial Least Squares Data Analytic Technique in Group and Organization Research. Group and Organization Management, 34, 5-36. https://doi.org/10.1177/1059601108329198

[61] Ringle, C.M., Sarstedt, M. and Straub, D.W. (2012) Editor's Comments: A Critical Look at the Use of PLS-SEM in "MIS Quarterly". Management Information Systems Quarterly, 36, iii-xiv. https://doi.org/10.2307/41410402

[62] Hair, J.F., Sarstedt, M., Ringle, C.M. and Mena, J.A. (2012) An Assessment of the Use of Partial Least Squares Structural Equation Modeling in Marketing Research. Journal of the Academy of Marketing Science, 40, 414-433. https://doi.org/10.1007/s11747-011-0261-6

[63] Nitzl, C. (2016) The Use of Partial Least Squares Structural Equation Modelling (PLS-SEM) in Management Accounting Research: Directions for Future Theory Development. Journal of Accounting Literature, 37, 19-35. https://doi.org/10.1016/j.acclit.2016.09.003

[64] Hair, J.F., Risher, J.R., Sarstedt, M. and Ringle, C.M. (2019) When to Use and How to Report the Results of PLS-SEM. European Business Review, 31, 2-24. https://doi.org/10.1108/EBR-11-2018-0203

[65] Ringle, C.M., Wende, S. and Becker, J.-M. (2015) SmartPLS 3. SmartPLS, Bönningstedt.

[66] Ringle, C.M., Wende, S. and Will, A. (2005) SmartPLS 2. SmartPLS, Hamburg.

[67] Garson, G.D. (2016) Partial Least Squares: Regression and Structural Equation Models. Statistical Associates Publishers, Asheboro.

[68] Gerbing, D.W. and Anderson, J.C. (1988) An Updated Paradigm for Scale Development Incorporating Unidimensionality and Its Assessment. Journal of Marketing 
Research, 25, 186-192. https://doi.org/10.1177/002224378802500207

[69] Chin, W.W. (1998) Issues and Opinion on Structural Equation Modelling. Management Information Systems Quarterly, 22, 7-16.

[70] Hair, J.F., Bush, R.P. and Ortinau, D.J. (2009) Marketing Research: In a Digital Information Environment. 4th Edition, McGraw-Hill Higher Education, Cape Town, 690.

[71] Henseler, J., Ringle, C.M. and Sinkovics, R.R. (2009) The Use of Partial Least Squares Path Modeling in International Marketing. In: Sinkovics, R.R. and Ghauri, P.N., Eds., New Challenges to International Marketing, Vol. 20, Emerald Group Publishing Limited, Bingley, 277-320.

https://doi.org/10.1108/S1474-7979(2009)0000020014

[72] Diamantopoulos, A., Siguaw, J.A. and Siguaw, J.A. (2000) Introducing LISREL: A Guide for the Uninitiated. Sage Publications, London. https://dx.doi.org/10.4135/9781849209359

[73] Koufteros, X.A. (1999) Testing a Model of Pull Production: A Paradigm for Manufacturing Research Using Structural Equation Modeling. Journal of Operations Management, 17, 467-488.

[74] Hair, J.F., Black, W.C., Babin, B.J. and Anderson, R.E. (2010) Multivariate Data Analysis. 7th Edition, Prentice-Hall, Upper Saddle River

[75] DeVellis, R.F. (2012) Scale Development: Theory and Applications. Vol. 26, Sage Publications, Thousand Oaks.

[76] Gaskins, J. (2013) Confirmatory Factor Analysis. http://statwiki.kolobkreations.com/wiki/Confirmatory_Factor_Analysis

[77] Ning, Y. (2014) Quantitative Effects of Drivers and Barriers on Networking Strategies in Public. International Journal of Project Management, 32, 286-297. https://doi.org/10.1016/j.ijproman.2013.04.003 